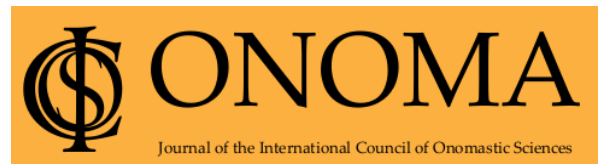

Onoma 56

Journal of the International Council of Onomastic Sciences

ISSN: 0078-463X; e-ISSN: 1783-1644

Journal homepage: https://onomajournal.org/

\title{
Not by any other name: The onomastics of government schools in New South Wales, Australia
}

\section{Colin Symes*}

Independent Researcher

Sydney, Australia

To cite this article: Symes, Colin. 2021. Not by any other name: The onomastics of government schools in New South Wales, Australia. Onoma 56, 251-268. DOI: 10.34158/ONOMA.56/2021/13

To link to this article: https://doi.org/10.34158/ONOMA.56/2021/13

(C) Onoma and the author.

\section{Article history}

Received on 29 July 2020.

Final form accepted on 11 December 2021.

Published online on 13 December 2021.

\section{Not by any other name:}

The onomastics of government schools in New South Wales, Australia

Abstract: The names of schools are a common enough feature of the "linguistic landscape", yet their character, structure and organisation, unlike that of other contemporary names, have not attracted much scholarly attention, something this paper endeavours to redress. It examines the names and onomastic properties of government schools in New South Wales (NSW), Australia, and the way their structures reveal much that is telling about the organisation of education across the state, both now and in the past. In so doing, school names provide both a means to identify a school and a means to project its identity, to flag its academic orientation, and as well 
as a semantic mechanism for their educational constituencies to identify with a school. Through their utilisation of a range of toponyms and anthroponyms that commemorate historical figures, school names reveal much about NSW's colonial origins.

Keywords: School names, toponymy, anthroponymy, onomastic culture, religious schools, state schools.

\section{Des noms qui ne doivent rien au hasard :}

\section{L'onomastique des écoles publiques de la Nouvelle-Galles du Sud, Australie}

Résumé : Les noms des écoles sont une caractéristique assez commune du « paysage linguistique ». Pourtant, leur spécificité, leur structure et leur organisation, à la différence de celles d'autres noms contemporains, n'ont pas tellement attiré l'attention des universitaires. Cette étude s'efforce de remédier à cela en examinant les noms et les propriétés onomastiques des écoles publiques de l'État de NouvelleGalles du Sud (Australie) et la façon avec laquelle leurs structures révèlent un grand nombre d'informations au sujet de l'organisation de l'enseignement dans tout l'État, aussi bien de nos jours que par le passé. Ce faisant, les noms des écoles permettent à la fois d'identifier une école, de refléter son identité et d'indiquer son orientation académique, mais fournissent également un mécanisme sémantique permettant d'associer des secteurs d'enseignement à une école. Les noms des écoles, qui utilisent une série de toponymes et d'anthroponymes commémorant des personnages historiques, en disent long sur les origines coloniales de la Nouvelle-Galles du Sud.

Mots-clés : Noms des écoles, toponymes, anthroponymes, culture onomastique, taxonomie des écoles, écoles d'état.

\section{Nicht unter einem anderen Namen:}

Onomastik der Namen staatlicher Schulen in New South Wales, Australien

Zusammenfassung: Schulnamen sind ein recht geläufiges Merkmal der „sprachlichen Landschaft“, allerdings haben ihre Besonderheiten, ihre Struktur und Organisation im Gegensatz zu anderen Namen unserer heutigen Sprache bislang in der Wissenschaft wenig Beachtung gefunden. Dies soll in diesem Beitrag nachgeholt werden. Wir untersuchen unter onomatologischen Gesichtspunkten die Namen der staatlichen Schulen in New South Wales (NSW), Australien, und analysieren, was wir aus der Struktur dieser Namen über die Organisation des Bildungswesens im gesamten Bundesstaat ableiten können, und zwar sowohl heute als auch in der Vergangenheit. Schulnamen dienen dabei sowohl als Mittel zur Kennzeichnung einer Schule als auch als Mittel, um ihre Identität nach außen zu vermitteln; sie lassen das pädagogische Leitbild der Schule erkennen und stellen einen semantischen Mechanismus dar, über den sich die Schulmitglieder mit ihrer Schule identifizieren können. Durch die Verwendung verschiedener Toponyme und Anthroponyme, die an historische Persönlichkeiten erinnern, verraten Schulnamen viel über die Kolonialgeschichte von NSW.

Schlüsselbegriffe: Schulnamen, Toponyme, Anthroponyme, Kultur der Namensgebung, Taxonomie der Schulen, staatliche Schulen. 


\section{Not by any other name: The onomastics of government schools in New South Wales, Australia}

COLIN SYMES

They use other countries' names here: Newcastle, Hamilton, Toronto, Aberdeen, for goodness' sake. Fancy using Scottish names.

(Liverani 1975: 196)

\section{Introduction}

Assigning a name to an area and parameters to its application are pivotal to emplacement, to the construction of linguistic landscapes. Such symbolic interventions, in conjunction with the landscape's calibration and measurement, provide mechanisms for "reading", addressing and mapping space and without which quotidian mobility, be it pedestrian or mechanical, would be unimaginable (Jensen 2013). Their material expression takes the form of street signage rationally and hierarchically deployed in the landscape, which is extended to that of buildings and other spaces. They display appellatives consistent with the requisite spatial protocols associated with the toponymic systems that underpin the management and negotiation of contemporary geographies, thereby enhancing their legibility (Certeau 1984; Rose-Redwood 2009). In due recognition of the importance of these systems in the smooth running of contemporary life (Moran 2005), there is now a corpus of literature examining the grammatical construction, meaning and etymologies of names found in the linguistic landscape, much of which displays critical dimensions. Among other matters, it has analysed the politically-contested nature of toponyms (Azaryahu 2009), the role that street names play in normalising language policies (Przymus 2017) and the degree to which colonialization has had a catastrophic impact on first nation toponymy (Carter 1987).

In these endeavours to understand the nomenclatural vagaries and functions of geographical names, those of educational institutions have received relatively little scholarly scrutiny, which is somewhat ironic given the roles schools play in embedding the mentalities required to read the linguistic landscape. Further, as schools are among the most ubiquitous institutions found in urban habitats, this oversight is particularly inexplicable, long overdue for redress. The handful 
of papers examining their onomastic profiles, though yielding insights about school and college names (Alderman 2002; Johnson \& De Vinne 2007; Logan 1937), deal with educational institutions in the United States of America (USA). Moreover, their particular focus is on schools named after people (anthroponyms) rather than places (toponyms) as is the practice in many other educational jurisdictions, including that of New South Wales (NSW), whose school names and syntactical construction are the subjects of this paper's analysis. ${ }^{1}$ For in another departure from the aforementioned literature, its analysis is predicated on the assumption that a school name comprises more than just an anthroponym or a toponym, that properly speaking its full name, that featured on its signboard, in its address, on its letterhead and uniform, consists of a second element. This consists of a remit of educational terms, subject to bureaucratic prescription, indicating the learning constituency a particular school or college services. Moreover, as a result of periodic policy change, these terms are subject to regular modification, requiring school names to undergo adjustment. The naming protocols of schools, which are in essence multi-referential ones, in other words cannot be isolated from the policy cultures that embed them.

This paper's approach to analysing the onomastic ethos of the state's schooling system is an archaeological and systematic one (Tent 2015). It is focused on identifying the leitmotifs prevalent among the names of the two thousand plus government schools in NSW and examining the provenance of those, which for various reasons, are anomalous. MySchool, a website developed by the Australia government allowing parents and other interested parties access to school performance measures, and which enables school names to be obtained by state, category and sector, was used as a primary source. ${ }^{2}$ The relevant name was then transferred to a spreadsheet along with other cognate information, obtained from the school's website, such as the year of the school's establishment, its motto and/or slogan, pertinent features about its badge and anything of salience relating to its name. In the process, the names were classified according to onomastic type: at least, in so much as it was possible to do so, for the distinction between anthroponyms and toponyms was not always transparent, and attempts to trace the genealogy of the former occasionally proved impossible. This paper's main concern, that of describing the naming profiles of NSW state schools and the policies underpinning them forms part of a larger project examining the signage practices of the state's schools, of which names are pivotal elements. Principal among the questions to be answered are what functions the government school name actually play. Less a focus of this paper's remit of interest are the state's private schools, which, as is evident from the names accorded them, are mostly religious ones.

\footnotetext{
1 School names are also applied internally to sporting teams (that have bellicose themes (Zeitler 2018)), houses and buildings.

2 https://www.myschool.edu.au
} 


\section{What's in a school name}

Like those associated with other cultural organisations, museums and libraries being cases in point, school names are "phrasal names" (Anderson 2007: 107), polynomial ones, which in NSW, as elsewhere, exhibit a binary structure, two contrasting elements. The first functions taxonomically and identifies the category or class of education to which a particular school belongs as well as its students' demography, either explicitly or implicitly. The main categories used in the NSW government sector are "public" which, stripped of its British associations, is applied to the state's primary schools and "high" which is applied to its secondary schools. Other Australia states and territories have adopted different educational taxonomies for their schooling systems, as have non-government schools. In Queensland primary schools are called "state schools" as are high schools, whereas in the Australian Capital Territory (ACT), Victoria, South Australia and Western Australia the word "primary" is used in both the government and non-government sectors. In Tasmania, primary is used exclusively by the government sector. In the name of distancing themselves from this sector, nongovernment schools in NSW omit "public" from their onomastic thesaurus.

The second element of the name functions more specifically and identifies the school by a proper name of some kind, thereby differentiating it from other schools of its type or class and rigidifying its designation (Van Langendonck 2007, 2015). In the vast majority cases of NSW government schools (Table 1), this name is a toponym, relates specifically to a school's locality. The name of those so assigned vary in their magnitudes and scale of urban coverage. A number, as is the practice in other Australian states, are named after NSW's largest cities (Sydney, Newcastle, Wollongong), followed by those of its regional centres (Bathurst, Orange, Armidale), followed by the still smaller and far more numerous urban settlements of towns and villages. The names of cities and towns tend to be applied to high schools, which, consistent with their names, have more extensive catchment areas than primary schools. The vast majority of NSW school names take their names from suburbs, of which there are myriad numbers in the state's "highly" suburbanised cities and regional centres. Their names have more toponymic exactitude than the diffuse city name, whose area of application is broader. To combat this diffuseness, it is not uncommon for such names, which are mostly applied to high schools some among the state's oldest - located near their city centres, ${ }^{3}$ to be additionally calibrated through "encompassment" (North Sydney), an onomastic distinction that is also applied to schools located in large suburbs (Bankstown, Liverpool). More precise from a positional stance are those school names that take the form of odonyms, that draw their names from the streets

3 There is one counter-example: Sydney Technical High School, which was moved from its original site in Paddington to Bexley, a suburb in the city's south-west. 
or roads on which they are located. Finally, there are those school names, fewest in number (2), that have adopted the names of the properties on which they are/were housed and which area-wise have the least diffuseness (Ferncourt Public School).

Table 1: Name classification according to type of school type

\begin{tabular}{|c|c|c|c|c|c|c|}
\hline Type of name & Infants & Primary & Secondary & Central & College & Special \\
\hline Toponym & 15 & 1549 & 298 & 53 & 38 & 18 \\
\hline Anthroponym & & 18 & 22 & & 3 & 10 \\
\hline Odonym & 1 & 50 & 1 & & & 6 \\
\hline Miscellaneous & & 10 & 10 & & & 27 \\
\hline
\end{tabular}

Naming protocols demand that the most generic information of all, that to which being referred in the name is a school (as applies with museums and libraries), is positioned at the name's conclusion. By contrast, that which its most specific that of its actual name, that which, to invoke the paper's title, in effect makes it like no other name, is positioned at its commencement. Other information deemed salient is located between these antithetical points, along a "syntactical axis" (Przymus 2017). A characteristic of this axis, as is illustrated in Table 2, is that each successive word in the school's name is collated in such a way that it is progressively more generic and paradigmatically less diverse than its immediate predecessor.

Table 2: The names of government schools located in Epping, one of Sydney's northern suburbs

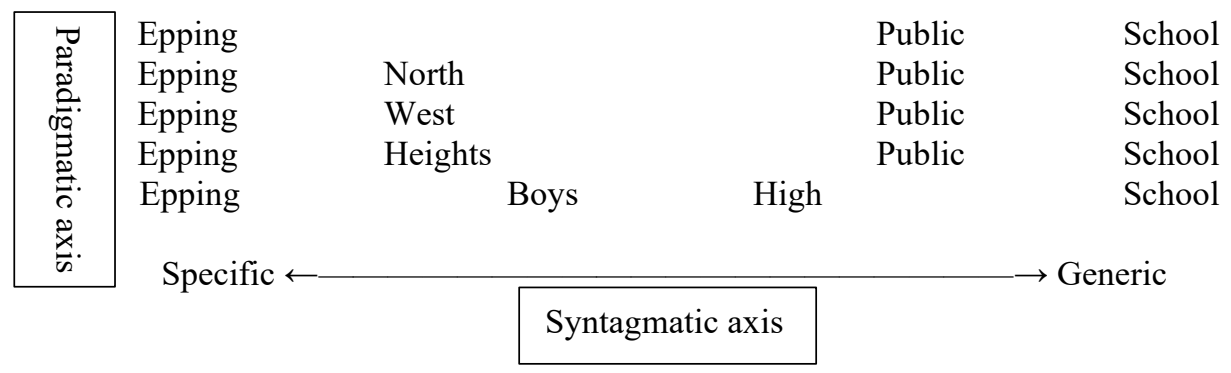

That which most is generic of all, school is all but rendered redundant by its preceding appellative elements, so much so, that in newspaper articles on schools, the word is often omitted, e.g. Epping Boys High, usually with its apostrophe absent. This accords with the policies of the NSW Geographical Names (sic) Board which proscribes the use of apostrophes, hyphens, inverted commas and other punctuation on government signage. ${ }^{4}$ Hence, while teachers inculcate the rules of apostrophe usage in their classrooms, the signs on school perimeters transgress them. Ironically though, it is not uncommon to observe

\footnotetext{
${ }^{4}$ For more details, see NSW Geographical Names Board website: https://www.gnb.nsw.gov.au
} 
correctly punctuated names on the stone porticoes of older schools and for some state schools to override the dictates of the Board, and from which the non-government sector appears exempt, for its schools' names apply accurate punctuation in their signage.

However, there is a point at which such reductionism, an aspect of the hypocorism associated with onomastic culture, can proceed no further, reaches a point where it becomes ambiguous, counterproductive. There are four other schools, all public ones which share the toponym Epping, and the only features that distinguish them, on paper at least, are their various categorial alignments, and without which they would display onomastic congruence. In other words, that which is in their names as well as being a statement of their institutional veracity, that boys and girls between the ages of five and eleven will be in attendance at the public school so named, such qualifying terms help to differentiate the school from its neighbouring schools - though not fully. That it does not leads to the toponym being calibrated in various ways, most often using points of the compass as in Epping West and North, usually after the name, to avoid the unsatisfactory onomastic outcome of many schools, with north, south, east and west as their "first" name. It ensures that encompassed schools are alphabetically listed together rather than as parts of an inventory of occidental or boreal schools. There are a few so named schools but this is usually because they are located in a suburb that is named west, south and so forth. There is also a chronological dimension to these onomastic processes, namely, that that the "disoriented" school is usually the first school established in a locality. Epping Public School was opened in 1901, twenty-six years before Epping North. And it is not unknown for such schools to be, as it were, reoriented, for their names to undergo syntactical inversion, as when Grafton South became South Grafton Public School after protests from the local council. ${ }^{5}$ Alternatively, the name might refer to a topographical feature as in Epping Heights, as the assignation south or east is potentially misleading, given the positions of Epping's other schools. The calibration of school names is thus by no means restricted to compass points but occasionally invokes other topographical features, e.g., vales, parks, hills, creeks, and which can give their names Arcadian nuances. By virtue of their frequency and more limited catchment areas, such nomenclatural nuancing is more common among primary than secondary schools.

Another toponymic option schools employ is that of the odonym, that of naming of schools after the road, avenue or street on which they sit or sat, e.g. Brooke Avenue, Bates Drive, Darcy Road. Its application is also, for the reasons outlined above, more prolific in the primary than the secondary sector (Table 1). The use of the trope was commoner in early days of NSW schooling, especially in Sydney, prior to the suburbanisation rail engendered (Spearritt 2000: 131). Hence, many schools which survive from the period retain their

5 Grafton South School is now South Grafton (Daily Examiner, 21 October 1951, 2). 
odonyms. The only NSW high school doing so is the state's oldest, Fort Street High School, which as befits its name, once had a fort at the end of its street (depicted on its badge), before it was moved, along with its odonym to its present location, in Petersham, in Sydney's inner west. Such is the school's status, it is frequently known as Fort Street, which also provides the source for the name of its alumni, Fortians. Another such odonym was Cleveland Street, which originally opened in 1856 as what was known at the time as a National School before becoming a Public School in 1867 and ending its days as the Cleveland Street Intensive English School. It remains a school but its original name has been dropped in favour of the recently gazetted Inner Sydney High School. ${ }^{6}$ This is indicative of the transitory nature of school names, of the fact that many undergo re-nominalisation during their histories. These have been engendered in the main by broad policy shifts involving schooling's prolongation, specialisation, comprehensivisation, integration, segregation and desegregation. They are reflected in the nomenclatural changes to the state's education system, especially its secondary sector. They are less a feature of the primary sector, which with the exceptions of the short-lived half-time and provisional schools, which, staffed by non-qualified teachers, were make-do institutions, in lieu of the real thing, has been dominated by the public school. It came on the educational scene during the 1860s when the then NSW government, headed by Henry Parkes, was committed to increasing educational egalitarianism and opportunity (Burnswood \& Fletcher 1980: 45), even if this meant housing some schools in tents, graced with names to suit (Cotton River Tent School)! As their names had more than a hint of inferiority about them, like provisional and half-time schools, they soon disappeared from the scene, once public schools existed in the numbers and locations to replace them. The other dominant category high school was first employed a decade or so later when the government opened four such schools in Goulburn, Maitland, Bathurst and Sydney - each with single-sex branches, which in the latter case persist through to the present, it is of note as selective schools, though this fact is not registered in their names.

With the demand for secondary education outpacing supply, so-called superior public schools filled the void. These were primary schools which provided secondary education in lieu of high schools which, with the exception of those mentioned, were an absent presence until the 1920s when, as a result of reforms to post-primary education recommended by the Knibbs-Turner Report, a number of specialist high schools in the areas of commercial, agricultural, technical and domestic education were established (Barcan 1988: 177-178). Along with the demise of the superior public school, their advent transformed the taxonomy

6 When the new school was announced and various names were canvassed, e.g. Metropark High, many of the school's alumni counselled the Department to retain the school's original name (Baker 2019). 
of NSW secondary education. As it was taken for granted that a domestic science school would be for girls only, just as a technical school (some of them "junior") would be for boys only, their names were gender neutral. The exceptions among this class of secondary schools were the so-called commercial schools which were co-educational, a reflection of the fact that at the time of their establishment increasing numbers of girls were entering offices as typists and stenographers. Indeed, most of the state's existing single-sex high schools (20 girls, 17 boys) stem from this period, the 1930s, and are, by and large, restricted to the Sydney conurbation.

The next phase of development in secondary education occurred during the 1960s, following the publication of the Wyndham Report. One of its main recommendations was the abandonment of specialist secondary education, which meant the commercial, technical and domestic high schools were converted into comprehensive ones. In onomastic terms, this meant they reverted to plain high schools with boys or girls added if apposite. One notable exception were the agricultural high schools, which survive to through the present, continuing to provide links between primary school and study at an agricultural college or university (Burnswood \& Fletcher 1980: 187). ${ }^{7}$ Hence, entrance to them was, and remains partially or wholly selective. The latter also applies to a number of high schools across the state, which also remained, by virtue of their age, exempt from Wyndham's reforms, and whose names were accordingly retained, e.g. Sydney Girls High School.

During the 1990s, following the election of a Coalition government in NSW committed to adopting neo-liberalist principles across the public sector, which in education terms entailed increasing choice and competition in the education system, there was a renaissance of secondary specialisation. It saw the development of niche schools, which saw requisite name changes to the designated high schools. Whilst the majority of NSW high schools maintained their comprehensive programmes, a few became inter alia Sports (3), Performing Arts (6), Visual Art and Design (1) and Technology (11) high schools. With the exception of a handful of technology highs, which were single-sex and accordingly designated thus (East Hills Girls Technology High School), they were all coeducational. At more or less the same time, there was an embrace of policies of integration, of social inclusiveness, that saw the closure of schools for students, to use the language of the time, with cognitive and motor deformities. For those students who are not eligible to be integrated into the mainstream school or need to be removed from such a school, there are still special schools available but their names are appellatively neutral, do not allude, as was the case in the past, e.g., Crippled and Sub-Normal Children (NSW Department of Education c2003: 18) to the disabilities of their learners, are just plain schools in other words, that is,

In due recognition of this role, Hurlstone was originally named Hurlstone Agricultural Continuation School. 
it goes without saying, with toponym or anthroponym added (Five Islands School).

One terminological relic of the past that thus far has not attracted much ideological odium is the infant school. ${ }^{8}$ It was first assigned during the $1880 \mathrm{~s}$ to a handful of schools that were opened in and around Sydney (many still operating, e.g. Taverners Hill Infants School) to ease the pressure on local public schools (NSW Department of Education c2003: 17), and still is so, albeit sporadically, to those schools with similar student profiles. Many were opened in the 1950s and the last was in Bankstown, in 1963. Its persistence reflects the fact that the taxonomy of early education is less subject to policy intervention, is more immutable than its secondary counterpart. Another taxonomical survivor from the past is the Demonstration School, which is retained by Fairy Meadow, in the Illawarra region. ${ }^{9}$ First applied in the 1920 s, it was used to designate schools used for teacher training.

Finally, there are various schools designed to overcome Australia's most intractable educational problem, that of remoteness, which the introduction of the so-called travelling school in 1909, whose original name Eton-Harrow did not attract universal approbation, attempted to overcome (Freeman 1993: 10). Such horse drawn schools were finally withdrawn from service in 1949. In the meanwhile, technology in the shape of radio, in the form of the School of the Air, based in Broken Hill, finally overcame, enabling school to be conducted at home and still continues (Symes 2012), increasingly in a digital format. Between the virtual and actual primary and high school is the so-called Central School which is - almost like the superior school of old - a federation of sorts between a primary and high school. There are 66 such schools located throughout the remote areas of NSW, mostly in regional centres considered too small to support a high school equipped with a full range of facilities (NSW Department of Education c2003: 15). They share some kinship to the Community School, a term introduced in the 1990s and applied to schools in the state, both in the city and the country (3 in number), which teach students from grades K to 12 .

A more recent nomenclatural development, that is mostly restricted to the state's urban centres and that is indicative of school's prolongation, that more students are continuing their schooling beyond the official leaving age, is the establishment of the so-called senior college or as it is sometimes known, secondary or community college. The use of the term college, new to the government sector, sounds "swankier" than the word school (Cottle 1983: 130). Devoid of the juvenile overtones associated with school, college is more compatible with the age-profile of its attendees. It has helped arrest the drift to private schools among Grade 11 and 12 students, especially in metropolitan

8 An article in the Sydney newspaper The Dawn is an exception. It argued that the word should be abolished from the vocabulary, that infants, rather than attending schools, should be outdoors, playing ("Too Much School", The Dawn, 1 May 1903, 14).

9 On its badge, North Sydney Public School also refers to itself thus. 
areas (Caldwell 2010: 381). In the main as multi-campus institutions, which occupy the campuses of former high schools, their composite names encompass, if they are toponyms at least, several municipalities or suburbs, e.g. Georges River Senior College. Their names in other words are more diffuse and generic than those of their antecedent high schools and reflect their broader catchment areas. In another attempt to dispel the anachronistic and institutional overtones attendant on school is the assignment of Learning Village to an innovative educational campus at Lindfield, on Sydney's North Shore.

\section{Humanising NSW schools}

Though nominally speaking the majority of NSW school names contain a toponymic element (the exceptions will be dealt with in the next section), suggesting that the primary imperative behind their raison d'être is informative, is that of indicating the presence of a government school in a particular area or region, a number of caveats apply to this observation. These in large measure stem from the processes by which Australia's topography underwent progressive Anglicisation, a process which saw the displacement of an indigenous onomastics (Tent \& Blair 2011: 67). The early explorers and surveyors who undertook the process of naming Australia employed a geographical taxonomy imported from Europe that proved manifoldly inadequate to label the continent's eccentric topography: glens were not glens, tablelands, tablelands and so on (Carter 1987: 45). And while words from local indigenous languages were not entirely eschewed, were eventually gazetted, their veracity has often been questioned; indeed, many were spurious neologisms, created to look and sound like Aboriginal words. ${ }^{10}$ But of more import is the fact that most of the English names applied to Australia's geography, but particularly that of NSW, be it mountains, rivers, cities, towns, suburbs, streets, properties were personal names, were anthroponyms. Many were direct appropriations of British toponyms, e.g. Epping, that were designed to evoke memories of the "mother" country. In other words, their denotative functions were coloured with connotative ones. However, they were soon overshadowed by the many names conferred on Australian localities that were designed to celebrate, though curry favour might be more apposite (Appleton \& Appleton 1992), important figures among the power elites of Regency and Victorian Britain. Arguably, the precedent was set with James Cook's voyage to Australia's eastern seaboard, one of whose outcomes was the naming of many of its features after eminent members of Endeavour's crew and influential figures in the Admiralty. During the first phase of Australia's colonisation, such onomastic practices were "normalised". Lachlan Macquarie, the first governor of NSW, named one town, now on the outer rim of Sydney, after his wife's maiden name (Campbell) and which was inflected to appear more toponymic-like as

10 See Indigenous entries included in Appleton \& Appleton (1992). 
Campbelltown. The same is true of Darlinghurst, in Sydney's CBD, which was named after one of NSW's early governors, Ralph Darling, whose name appears throughout Australia (Appleton \& Appleton 1992: 84-85). Hence, while on the surface many of Australia's toponyms appear to be toponyms they are in effect anthroponyms in disguise - not all of them necessarily inflected to look more place-like. Indeed, the pantheon of personages upon whom Australia's early "onomasticians" drew for their place names, eventually extended beyond governors and their entourages, explorers and surveyors, to include reformed convicts who left their mark on the colony in some tangible way such as John Glade, who pioneered the suburb of Gladesville. Incidentally, this also includes some indirect biographical allusion to the personage, such as the home town of a colonial official, as is the case with Artarmon, a suburb in north Sydney, which takes its name from the Irish hometown of one of the colony's first provost marshals, William Gore (Appleton \& Appleton 1992: 10). Others had a literary provenance, e.g., Sydney suburb Auburn, which "featured" in Oliver Goldsmith's poem "The Deserted Village". ${ }^{11}$ Such literary names are occasionally assigned to places with names that their community found unattractive. This was the case with Oberon, whose original name Glyndwr was held dysphonic and was changed to its current one at the urging of a local Shakespeare enthusiast.

Even though many of the genealogical connections inherent in NSW place names have faded into the annals of history, need to be exhumed from dictionaries of Australian toponyms to be identified, there are some names such as Leichhardt, Bankstown and Blaxland whose genealogical connections are not esoteric, though their connection to the schools thus tagged is in many instances remote. Although the explorer Gregory Blaxland did have connections with the Blue Mountain's town of Blaxland, that is not the case with Ludwig Leichardt and the suburb of Leichhardt, or Joseph Banks and Bankstown! However, there are some 70 government schools - not large when compared with the corpus of schools across the state - which have genuine anthroponyms, though in some instances the name is only partially expressed as a surname and therefore is sometimes difficult to recognise as such.

If there is a preponderance of religious "celebrities" among the anthroponyms of non-government schools, then it is secular ones, who populate those of government sector, which by statute is an avowedly secular one. The qualifications of the eminent citizens, almost of whom have some direct association with New South Wales, like their overseas' counterparts play a part in sustaining the nation's "collective memory" (Alderman 2002: 604). They begin right at Australia's European beginnings with James Cook. A Technology Boys High Schoo ${ }^{12}$ close to Botany Bay, where Cook made his landfall, is suitably adorned with his name, whilst another, in Revesby, is graced with that of his botanist,

11 This literary toponym is found elsewhere in Australia, and in Canada and the USA.

12 It was not always thus: it opened in 1956 as Moorefield Boys High School before assuming its current name, James Cook Boys Technology High School, in 1990. 
Sir Joseph Banks, who owned a country house called Revesby. Unusually for a school name - only two others do ${ }^{13}$ - it includes Banks' knighthood, yet there is no shortage of such titles and honours among those names selected for schools to bear. Yet they are sometimes omitted in their "scholastic" dedications as are their first names, which further de-anthropomorphises them. Typical is Denison College, which opened in 2007 and which honours a former NSW Governor General, Sir William Denison, who was an advocate of schooling. In fact, a number of governors, both from the colonial and modern eras, feature among school names (Arthur Phillip, Marie Bashir) - in these instances, in their full form. To them, one could add ex-premiers of NSW (J. J. Cahill) and one Australian Prime Minister (Ben Chifley), influential public servants, especially in the Department of Education (Sir Harold Wyndham) and members of the armed services, e.g. Frank Partridge, who was a Victoria Cross recipient. His name graces a public school in Nambucca Heads, close to Macksville, Partridge's birthplace, and whose badge takes the form of a Victoria Cross. There are also two other significant features of the anthroponyms and that is that they sometimes include the word memorial, as in The J. J. Cahill Memorial High School, which honours a premier of the state. A definite article gives added distinction to its name, though its deployment is by no means rare (e.g., The Jannali High School).

Robert Townson High School on the other hand, is named after a gentleman scholar, who was granted land in the Minto district by Lachlan Macquarie in 1806, close to where the school is located. Indeed, many schools are named after persons with close connections to the land. They include the agricultural high schools discussed earlier, of which the most famous, by dint of its academic reputation, is James Ruse Agricultural High School. It was originally graced with a toponym, that of Carlingford, until the school's first principal discovered the important role James Ruse, an ex-convict who was allotted land by Arthur Phillip, played in demonstrating the agricultural potential of Sydney's northwestern rim, where the school is located, in the colony's early-days. That it was the school's inaugural principal who urged the school's original name be abandoned is a reminder that the NSW community is afforded the opportunity to nominate names for its schools. Indeed, Ruse is not the only ex-convict to grace the nameboard of a state school: at least five others do, which makes it the second most popular category of educational anthroponyms after that of NSW governors! The least popular is that of engineers, of which there is just one, namely, John Bradfield, whose name has been assigned to a North Sydney college, close to the famous Harbour Bridge he engineered. There are three eminent Australian writers (Henry Lawson, Henry Kendall and Miles Franklin)

13 They are Sir Eric Woodward School, which honours a former governor of NSW, though the school, a special purpose one, is better known by its acronym, SEWS, and The Sir Henry Parkes Memorial Public School. Memorial also figures in Hay War High Memorial School, which opened in 1918, and has a war memorial on its campus. 
commemorated in school names and which are located in the districts (Grenfell, Gosford and Tumut) from which the said writers either hailed or had some association. The absence of any composers, scientists, mathematicians and artists among the remit of school anthroponyms is revealing about the culturalpolitics of NSW education, that governors and ex-convicts who redeemed themselves are seen as more apposite models to inspire pupils than educational or cultural ones (Alderman 2002: 606). Surprising too, given the degree to which they are laureated in Australian culture, is the dearth of sports people among school names: one to be precise, Bert Oldfield Public School, which takes its name from a cricketer of some renown and who served as a soldier in World War I, which, given that soldiers are a favoured anthroponym, helped to reinforce its credentials.

It is of note too that the names are overwhelmingly Anglo-Celtic ones, which is at loggerheads with Australia's multiculturalism. And they are not particularly socially inclusive: there are only a few women among them (7) including the aforementioned Miles Franklin and Marie Bashir, and none, so far as can be identified at least, has an indigenous background. Interestingly, at least one of the women remembered in a school name, Caroline Chisholm, famed for her humanitarian work with convict women, is so in two schools, one of which happens to be private. And another exists as a double-barrelled name, one blending a toponym and anthroponym, that for Maitland Grossman High School, which commemorates the role Jeanette Grossman, the first headmistress of Maitland Girls' High School (now merged with the local boys' high school), played in managing the school and billeting some of its students in her home. School mergers, which are not uncommon, usually results, unlike the Maitland example, in the conferring of a wholly original name.

Nor is the repository of possible names restricted just to human beings. They also include biotic names assigned to the names of towns and suburbs, such as flowers (Boronia, Rosemeadow), and which grant their associated schools an aesthetic aura. However, there are at least four schools in NSW, independent of their locality, named after native trees and flowers: Ajuga, Casuarina, Lilli Pilli and Mimosa and which are illustrated on their badges.

\section{To name but a few}

There are other school names which deviate from the aforementioned onomastic paradigms, that are neither toponymic nor anthroponymic - at least in the formats referred to above. As to whether toponyms apply to the night sky or not is a moot point, but in the Australian context the constellation of the "Southern Cross" has national significance: it is an emblem on in its flag. It is therefore not surprising that a number of its educational institutions (14 to be precise, with 4 in NSW), of which one is a university and another a specialist in Distance Education, include "Southern Cross" as an element of their names. Moreover, references to 
the constellation are included in their badges' iconography and in one case, that of Southern Cross High School (Ballina), in its motto, which has a starry theme, "Ad astra" - or did, until it was closed to form the basis of a so-called super-school. And while focusing on "higher" matters, another school, located in Castle Hill, Sydney, adopted a word for its name, a Latin one at that, more often found in the context of school mottoes, viz., Excelsior - and which the school's slogan further reinforces: "high ideals, high expectations, high achievement". It is a rare instance of language other than English being used as a school name, which raises the issue of Aboriginal languages and their use in the public domain.

Although indigenous languages are prevalent among New South Wales toponyms, other than those which attach themselves to towns and suburbs, a few of which have coprological overtones that many might find distasteful especially in school settings, ${ }^{14}$ the number of schools employing indigenous words in their names is relatively few. One is Billabong High School in Culcairn - though billabong meaning 'lake' in the local indigenous language has long since been vernacularised courtesy of the nation's de facto national anthem "Waltzing Matilda". Indeed, efforts to indigenise the toponymic landscape, such as that attempted in the Grampians, have encountered considerable opposition and have been abandoned (Kostanski 2011: 255). Arguably, all is not lost though. Through a process of osmosis, indigeneity is creeping into the onomastic culture of NSW education. One high school, which opened in 2015, draws its name from the indigenous people, the Cammeraygal, who once occupied the lands in north Sydney where the school is located. These linguistic affirmations of cultures and societies that predated Australia's Europeanisation might do little to redress the catastrophic assaults on its first peoples and their resultant marginalisation but they at least provide poignant reminders for succeeding generations of students of an Aboriginal presence in the schools they attend. A recent and especially poignant example of such linguistic miscegenation is that of a special purpose school, Yandalorra, which means 'land of peace between peoples' and whose website gives expression to this sentiment, indicating a commitment to maximising the opportunities of all students, regardless of their abilities or backgrounds.

In a complete departure from any of these naming traditions is that of a government college in Ryde, which describes itself as a virtual high school, as being in the vanguard of learning. In line with this description, it has a name from Greek mythology, that of the Goddess of dawn, Aurora, which also signifies a manifestation of the educational branding now creeping into schooling systems as a result of their "endogenising" business approaches (Ball \& Youdell 2008). Finally, there are those school names which are located in the material world, albeit ones from the state's historical past - in this instance, various modes of transport. One is the Zig Zag Public School, in the Blue Mountains, which is named after a nearby section of railway, which represented a considerable

14 The north-west NSW town of Coonabarabran is a case in point (Appleton \& Appleton 1992: 75). 
engineering feat for its time, and which also figures on the school's badge. The other transport category of name represented in New South Wales schools is that of the ship. As has been noted, schools are not averse to celebrating Australia military history in their names, as in their propensity to honour $\mathrm{VC}$ recipients. But in one case, this extends to ships, to be precise, a hospital ship, belonging to the Australian navy, which was sunk, during World War II, with considerable loss of life, not far from the school which bears its name, Centaur Public School, on the NSW/Queensland border. Another instance, returns the narrative to Australia's European beginnings, to a sport's high school, again in the shadow of Botany Bay, which has the name Endeavour, that of the ship on which Cook sailed to the antipodes and which is also writ large, so to speak, by the number of schools choosing Endeavour as their motto along with Cook's vessel on their badges!

\section{Conclusions}

While their names are a relatively minor and inconsequential elements in the overall performance of schools, their power as signifiers ought not be downplayed. The fact that some schools have good names, others bad ones, is indicative of the reputation that a name can carry, that some names can be positively toxic, while others can carry with them an aura, that invokes admiration and respect. In an era when impressions count, an arresting name, able to generate attractive educational nuances, is probably going to become the way of the future and there are signs (literally), even in the government sector, of such tendencies afoot. For the moment though, as this paper has argued, those found on the government schools of NSW are very much products of the past, of the traditions from which the sector draws its organisational and policy imperatives. As semantic clusters of words, the names assigned to schools are products of the rational state, are far from being arbitrary constructions, sans design or programmatic intent. This is at its most manifest in the institutional elements of the school name, which indicate that part of the system to which a particular school belongs, and which have altered over time. In the 1990s there was a shift away from the comprehensive high school to the specialist one that preceded it, albeit with new specialisations. In the 2000 s, there has been a drift towards sectioning off the senior years, Grades 11 and 12, and corralling them into institutions called colleges, which are more benign and adult sounding institutions than schools. In other words, the generic components of the school name reveal much about the shifts and changes in the patterns of educational provision across NSW. Its other component, that which individualises the school or college, gives it an identity as it were, is relatively homogeneous, especially in the government sector, where most schools are assigned toponyms - generally that associated with their location, be it a road or the name of their immediate suburb. It has been argued that these toponyms are more often than not embedded in a repository of references, owing much to the etymology of sources from which the name is 
derived. The names inscribed on the landscape of NSW were direct imports from the United Kingdom, were often eminent figures in that nation's Regency and Victorian history and were often much utilised. The other major trend in school naming - although it is far less common in NSW than in the USA - is that of utilising anthroponyms. According to this paper's analysis, the major figures represented in school names are drawn from the colonial period of NSW history, many of them ex-convicts who were given land-grants close to the schools that they now name. Otherwise the other protagonists figuring in school names are politicians, senior bureaucrats and state governors - mostly men, with a just handful of women. Thus far, unlike in the USA, such onomastic patronage has yet to attract much, if any controversy. The places and persons from which school names are constructed provide capsules of history, chronicling much that is telling about Australia's colonial and recent past. Through using words and names from indigenous languages, there are now attempts to render the onomastic repository of school names more socially inclusive and representative, to broaden its linguistic spectrum. School names then, are more than mere functional identifiers, aids to navigation; they have the potential to reveal much about the histories of place and emplacement, and the power with which some were invested to bequeath names on the linguistic landscape. Further, communities should take advantage of the opportunity afforded them to confer names on their local schools and to draw them from cultural sources that have hitherto only received limited onomastic representation.

\section{References}

Alderman, Derek H. 2002. School names as cultural arenas: The naming of U.S. public schools after Martin Luther King, Jr. Urban Geography 27(3), 601-626.

Anderson, John M. 2007. The grammar of names. Oxford: Oxford University Press. Appleton, Richard \& Appleton, Barbara. 1992. The Cambridge dictionary of Australian places. Cambridge: Cambridge University Press.

Azaryahu, Maoz. 2009. Naming the past: The significance of commemorative street names. In Berg, Lawrence \& Vuolteenaho, Jani (eds.), Critical toponymies: The contested politics of place naming, 53-84. Farnham: Ashgate.

Baker, J. 2019. What's in a name? For Cleveland St High Alumni, its everything. The Sydney Morning Herald, 2 December.

Ball, Stephen \& Youdell, Deborah. 2008. Hidden privatisation in education. Brussels: Education International.

Barcan, Alan. 1988. Two centuries of education in New South Wales. Kensington, NSW: University of New South Wales Press.

Burnswood, Jan \& Fletcher, Jim. 1980. Sydney and the Bush: A pictorial history of education in New South Wales. Sydney: New South Wales Department of Education. 
Caldwell, Brian J. 2010. Is private schooling becoming the preferred model of school choice in Australia? Journal of School Choice 4(4), 378-397.

Carter, Paul. 1987. The road to Botany Bay: An essay in spatial history. London: Faber and Faber.

Certeau, Michel de. 1984. The practice of everyday of life. Berkeley: University of California Press.

Cottle, Basil. 1983. Names. London: Thames and Hudson.

Freeman, Ashley. 1993. The travelling schools of New South Wales 19081949. Education in Rural Australia 3(1), 7-18.

Jensen, Ole. 2013. Staging mobilities. London: Routledge.

Johnson, Beth DiNatale \& De Vinne, Christine. 2007. A flock of doves: U.S. women's colleges and their names. Names 55(3), 199-228.

Kostanski, Laura. 2011. Signs of the times: Changing names and cultural values in Australia. Onoma 46, 251-274.

Liverani, Mary Rose. 1975. The winter sparrows: Growing up in Scotland and Australia. Melbourne: Thomas Nelson.

Logan, K. Otto. 1937. Do public school names have any educational significance? The Social Studies 28(8), 339-342.

Moran, Joe. 2005.Reading the everyday. London: Routledge.

NSW Department of Education. c2003. Government schools of New South Wales 1848 to 2003. Sydney: Department of Education and Communities.

Przymus, S. D. 2017. The subliminal influence of streetsigns in schoolscapes: Elective vs. circumstantial indexicality in a tale of two Tucsons. Journal of Second Language Acquisition and Teaching 24, 4-24.

Rose-Redwood, Reuben. 2009. Indexing the great ledger of the community: Urban house numbering, city directories and the production of spatial legibility. In Berg, Lawrence \& Vuolteenaho, Jani (eds.), Critical toponymies: The contested politics of place naming, 199-225. Farnham: Ashgate.

Spearritt, Peter. 2000. Sydney's century: A history. Sydney: University of New South Wales Press.

Symes, Colin. 2012. Remote control: A spatial history of correspondence schooling in New South Wales, Australia. International Journal of Inclusive Education 15(5-6), 503-517.

Tent, Jan. 2015. Approaches to research in toponymy. Names 65(2), 65-74.

Tent, Jan \& Blair, David. 2011. Motivations for naming: The development of toponymic typology for Australian placenames. Names 59(2), 67-89.

Van Langendonck, Willy. 2007. Theory and typology of proper names. Berlin: Mouton de Gruyter.

Van Langendonck, Willy. 2015. Names and grammar. In Hough, Carole (ed.), The Oxford handbook of names and naming, 18-31. Oxford: Oxford University Press

Zeitler, Ezra J. 2018. A taxonomy of secondary school athletic team names and mascots in the United States. Names 66(4), 219-232. 